\title{
BENEFITS OF OIL PALM EMPTY FRUIT BUNCHES COMPOST TO INCREASE THE POPULATION OF BENEFICIAL BACTERIA, GROWTH, AND YIELD OF PAKCOY ON INCEPTISOLS
}

\author{
Mieke Rochimi Setiawati, Reginawanti Hindersah and Pudjawati Suryatmana \\ Soil Science Department, AgricultureFacultyof Universitas Padjadjaran, Indonesia \\ Jl. Raya Bandung Sumedang Km 21 Jatinangor Kab. Sumedang 45363, Indonesia
}

https://doi.org/10.35410/IJAEB.2021.5611

\begin{abstract}
Inceptisols is quite wide in Indonesia but is not always a fertile soil and have enough organic matter content for agricultural production. Inceptisols fertility can be improve with organic fertilizers such as oil palm empty fruit bunch (EFB) compost accompanied with inorganic fertilizers. Oil palm EFB compost enriched with PGPR microbes is expected to reduce the use of inorganic fertilizers on pakcoy plants. The treatments of experiment were a of oil palm EFB compost 10 ton ha- 1 and without EFB aplication combined with 50, 75, and $100 \%$ doses of inorganic fertilizers. Randomized block design was used with repeated 4 times in plot experiment on the Inceptisols soil. The results showed that oil palm EFB compost treatment which was enriched with PGPR bacteria, can increase the population of beneficial bacteria in soil, growth and yield of pakcoy. Application 10 ton ha-1 of oil palm EFB compost combined with an inorganic fertilizer of $75 \%$ from recommended dose have a high fresh weight of pakcoy plants i.e $287.77 \mathrm{~g} / \mathrm{plant}$ or $6.64 \mathrm{~kg} / \mathrm{plot}$.
\end{abstract}

Keywords: Azotobacter, Azospirillum, Phosphate Solublilizing Bacteria, oil palm empty fruit bunch (EFB) compost, pakcoy, Inceptisols.

\section{INTRODUCTION}

Inceptisols are agricultural land with a fairly wide distribution in Indonesia, its distribution reaches approximately 70.52 million hectares (Puslittanak, 2000). This is a potential to be developed in the expansion of various agricultural commodities. Inceptisols soil is not always have fairly good soil fertility and organic matter because Inceptisols have low organic matter and acidic soil reactions (Abdurachman, 2016). According to Sudirja et al. (2019), the poor chemical properties of Inceptisols because of the low amount of soil organic carbon and total $\mathrm{N}$-soil, that cannot support to optimal plant growth. According to Ramadhan et al. (2014), Inceptisols are soils have moderate to low fertility. Inceptisols have a slightly acidic $\mathrm{pH}(6.4)$, low in total $\mathrm{N}$ $(0.17 \%)$, generally low in available $\mathrm{P}(12.14 \mathrm{cmol} . \mathrm{kg}-1)$ and moderate content in potassium (28.25 cmol.kg-1).

To overcome the problem of Inseptisols fertility, it is necessary to provide optimal inorganic fertilizer input. Nitrogen, phosphorus and potassium are essential macro nutrients that are used in large quantities and cannot be replaced with other nutrients. However, inorganic nutrients are 
Vol. 06, No. 01; 2021

ISSN: $2456-8643$

often deficient in supply due to low fertilization efficiency. The application of organic fertilizers can increase the efficiency of inorganic fertilizers. Based on the research of Sugiyanta et al. (2008) application of organic fertilizers can increase inorganic fertilizers efficiency by about $50 \%$. Although the contribution of macro nutrients from organic fertilizers is relatively small, around $0-10 \%$ and depends on the level of mineralization of the organic matter. The application of inorganic fertilizers is intended to increase nutrients in the soil and plant, because the nutrients in the soil of Inceptisols are low.

Organic matter is a nutrient contributor to soil has an important role. Organic matter derived from plant residues containing essential nutrients for the soil will accumulate as a source of nutrition for plants. Stable organic matter (humus) functions are to adsorb and retain nutrients in the form available to plants. The addition of organic matter increase the population of nitrogenfixing bacteria as available nitrogen source and reduce the inorganic fertilizer dose application (Bot and Benites, 2005). The application of organic fertilizers and inorganic fertilizers in properly composition is the important factor to maintain soil quality and sustainable agricultural yields. This fertilizer maintain optimal soil biological and chemical processes that ensure plant nutrients are available in sufficient and balanced quantities.

Agricultural waste product is an abundant source of organic matter. Oil palm empty fruit bunch (EFB) is the largest waste produced by oil palm plantations. The amount of EFB reaches 30-35\% of the weight of the fresh fruit bunch every harvest. However, until now, EFB waste utilization has not been used optimally (Hambali et al., 2007). Based on BPS data (2018), the total area of oil palm plantations in Indonesia in 2018 was 12,761,586 hectares. As much as $25-26 \%$ of the total oil palm production is EFB. This means that in 2018 around 9,148,500 tons of EFB were produced and it has the potential to be used as organic fertilizer. Based on the research of Syafwina et al. (2002) EFB contains the important organic material such as cellulose 37.346.5\%, hemicellulose $25.3-33.8 \%$ and lignin $27.6 \%-32.5 \%$. With a high content of complex carbon compounds, and EFB will be more useful when composted. Oil palm empty fruit bunches can improve soil improvement quality and serve as a nutrient source for cultivated plants or crops. EFB contains $0.91 \%$ N, 2.13\% P and 6.68\% K Siddiquee et al. (2017).

The application of empty bunch compost to oil palm plants can reduce the use of chemical fertilizers by $50 \%$ and a higher production compared to the application of $100 \%$ chemical fertilizers (Hatta et. al., 2014). The amount of compost that is applied to soil will have an impact on plant growth and yield. Based on the research of Kurniawan et al. (2016) using 10 tonnes of ha-1 of compost for empty bunches of oil palm combined with $75 \mathrm{~kg}$ ha-1 of inorganic fertilizers resulted in a corncob weight of $3.78 \mathrm{~kg}$ without husked plot-1. Compost made from agricultural waste from empty palm oil bunches (EFB) can be used to support the growth of pakcoy plants and reduce the use of inorganic fertilizers. EFB organic fertilizers can also increase the population of heterotrophic soil microbes which are beneficial as a source of energy and nutrients. The population of beneficial bacteria in the soil such as $\mathrm{N}$-fixing bacteria, namely Azotobacter sp., Azospirillum sp. and phosphate solubilizing bacteria, most of which are heterotrophic microbes, will increase in population with the presence of EFB compost. Inoculation of compost with cellulose decomposing isolates may increase N2-fixing activity (Kostov et al., 1991). Keeling et al. (1994) mentioned that compost which rich in lignocellulose has potential to improve the N2-fixing activity and properties. Organic materials can increase a sufficient amount and activity of soil microbes (Siddiqui et al. 2009). Naturally, there are 
Vol. 06, No. 01; 2021

ISSN: $2456-8643$

endogenous microbes in the rhizosphere that can provide nitrogen and phosphate nutrients such as for activating nitrogen fixing bacteria (NFB) and phosphate solubilizing bacteria (PSB).

Pakcoy can be categorized into leaf vegetables based on the portion consumed. This plant contains $93 \%$ water, $3 \%$ carbohydrates, $1.7 \%$ protein, $0.7 \%$ fiber, and $0.8 \%$ ash and is the source of vitamins and minerals such as B-carotene, vitamins $\mathrm{C}$, calcium, phosphate, and iron (Elzebroek \& Wind, 2008). Currently pakcoy is easily obtained in the market in Indonesia so that it can be ascertained that the market demand is quite high, but the quality and quantity that exist in the market today still varies. Based on the background description, it is expected that the EFB compost application can reduce the use of inorganic fertilizers and increase the total population of useful soil functional microbes, growth and yield of pakcoy plants on Inceptisol soil. The purpose of this study was to determine the combination of EFB compost with the dosage of inorganic fertilizers in increasing the beneficial soil microbial population,growth and yield of pakcoy plants.

\section{MATERIALS AND METHODS}

The experiment was carried out in the Ciparanje experimental field, Jatinangor District, Sumedang Regency, West Jawa with an altitude of 829 meters above sea level. The area around the experimental was given gauze to minimize pests attack.

The experimental soil used was the Inceptisols which had the characteristics, $\mathrm{pH}$ was 6.4 (slightly acidic), $1.98 \%$ organic carbon (low), $0.17 \%$ total-N (low), and C/N was 12 (moderate). P2O5 was low (12.14 ppm), while total $\mathrm{P}$, total $\mathrm{K}$, cation exchange capacity (CEC), and base saturation were categorized as moderate, were respectively $35.02 \mathrm{mg} / 100 \mathrm{~g}, 28.25 \mathrm{mg} / 100 \mathrm{~g}$, $21.51 \mathrm{cmol}$. kg-1 and 57.08\%. Cation exchangeble $\mathrm{Na}$ and $\mathrm{Ca}(0.73$ and $9.62 \mathrm{cmol} . \mathrm{kg} 1)$ were moderate, while K was 0.93 cmol.kg-1 (high) and Mg 1.00 cmol.kg-1 (low). The Pak choy seeds used was the Nauli F1 variety. The inorganic fertilizer used wereUrea (48\% N), Single phosphate SP-36 (36\% P2O5), and Potassium chloride $\mathrm{KCl}(56 \% \mathrm{~K} 2 \mathrm{O})$ as treatment. Compost made from agricultural waste as treatment used oil palm empty fruit bunches (EFB) compost from the oil palm processing factory PTPN 8 Cigudeg Bogor. The EFB compost content were $8.66 \%$ water content, $39.28 \%$ organic carbon, total $\mathrm{N} 1.63 \%$, and $\mathrm{C} / \mathrm{N}$ was 24 .

The experimental design carried out was a randomized block design (RBD) consisting of 6 treatments. Each treatment was repeated 4 times, in order to obtain a total treatment of 24 plots. The treatments given are as follows.

$\mathrm{K} 0 \mathrm{~N} 1$ = without EFB compost + inorganic fertilizer $50 \%$ recommended dose $\mathrm{K} 0 \mathrm{~N} 2$ = without EFB compost + inorganic fertilizer $75 \%$ recommended dose K0N3 = without EFB compost + inorganic fertilizer $100 \%$ recommended dose $\mathrm{K} 1 \mathrm{~N} 1$ = EFB compost $10 \mathrm{t}$ ha- $1+$ inorganic fertilizer $50 \%$ recommended dose $\mathrm{K} 1 \mathrm{~N} 2=\mathrm{EFB}$ compost $10 \mathrm{t}$ ha-1 + inorganic fertilizer $75 \%$ recommended dose $\mathrm{K} 1 \mathrm{~N} 3=\mathrm{EFB}$ compost $10 \mathrm{t}$ ha-1 + inorganic fertilizer $100 \%$ recommended dose 
Vol. 06, No. 01; 2021

ISSN: $2456-8643$

The recommended dosage of inorganic fertilizer for pakcoy plants is $300 \mathrm{~kg}$ ha- $1 \mathrm{urea}, 200 \mathrm{~kg}$ ha$1 \mathrm{SP}-36$, and $200 \mathrm{~kg}$ ha- $1 \mathrm{KCl}$. EFB compost enriched with bacterial isolates that function as Plant Growth Promoting Rhizobacteria (PGPR) isolated from termite nests. The PGPR bacteria consist of Azotobacter sp., Azospirillum sp., and Phosphate Solubilizing

Bacteria (PSB) with each population density above108 CFU/ml. The dosage of EFB compost 10 ton ha-1 was given to the treatment plot by mixed evenly on $1.5 \times 1 \mathrm{~m}$ beds and incubating for a week. Pakcoy seeds that were growing 2 weeks at the nursery were transplanted to the experimental field with a spacing of $25 \times 25 \mathrm{~cm}$. Urea, SP-36 and $\mathrm{KCl}$ fertilizers were added in an array. The maintenance carried out on pakcoy plants includes embroidery, watering, controlling pests and diseases. Rhizosphere soil sampling for microbial analysis and harvesting of pakcoy was carried out at 4 week after plant (WAP).

\section{RESULTS AND DISCUSSION}

Beneficial Soil Microbial Populations All beneficial soil microbes such as Azotobacter, Azospirillum, and Phosphate Solubilizing Bacteria (PSB) increased their population by given EFB compost organic fertilizer. The application of inorganic fertilizers with increasing doses according to recommended doses did not increase the beneficial soil microbial population. Even reducing the dosage of inorganic fertilizers on soil treated with EFB compost tend to increase the Azotobacter, Azospirillum, and PSB populations.

The application of EFB compost to the soil was not only playing a role in increasing soil organic carbon, but also added millions of microorganisms so that it was triggering the development of Azotobacter sp. population. The highest Azotobacter population was shown on the application of EFB compost 10 ton ha-1 accompanied by inorganic fertilizer 50\% recommended dose. Meanwhile, Increasing the dose of inorganic fertilizers reduced the population of Azotobacter sp. Azotobacter population appears to be inhibited by the addition of inorganic fertilizers, especially nitrogen fertilizers. The decrease in the population of Nfixing microbes can be caused by decreasing in $\mathrm{pH}$ due to the application of high doses of $\mathrm{N}$ fertilizers. In line with Mujiyati and Supriyadi's (2009) research, giving inorganic fertilizer can reduce soil $\mathrm{pH}$ to 6.31 compared to soil $\mathrm{pH}$ with manure treatment and soil $\mathrm{pH}$ without treatment (control) 7.08. Meanwhile, Azotobacter bacteria are more commonly found in neutral soils, so the addition of inorganic fertilizers to the planting medium which lowers the $\mathrm{pH}$ can suppress the growth of Azotobacter. The provision of EFB compost combined with the increasing doses of inorganic fertilizers does did not influence Azospirillum sp population. It seems that Azospirillum is more resistant to the given doses of inorganic fertilizers. Several species of Azospirillum can be associated into plant root tissue (endophytic) so that direct contact with doses of inorganic fertilizers can be avoided which can interfere with the activity of cell division. Suryatmana et al. (2020) stated that Azospirillum is an associative symbiotic nitrogen-fixing bacterium that is active in plant root tissue. Azospirillum bacteria require low oxygen conditions, and can grow rapidly in environments that have ammonium but can not fixing nitrogen activity. Azospirillum is a 
bacterium that can encourage the growth of various types of plants, because of its ability to produce phytohormones, including gibberellins.

The population of the phosphate solubilizing bacteria (PSB) increased with the addition of doses of inorganic fertilizers in the treatments that were not given EFB compost. In contrast, with EFB compost, the PSB population was the highest at the smallest inorganic fertilizer dosage (K1N1). This is presumably due to the medium total $\mathrm{P}$ content of the soil while the available $\mathrm{P}$ content of the soil is low. With the provision of EFB compost, it will provide sufficient nutrition and energy for heterotrophic PSBs to reproduce. Whereas in the application of high doses of inorganic fertilizers, SP36 fertilizer with high P availability did not stimulate PSB activity in dissolving P in the soil. This opinion is in line with Sarapatka (2003) which states that microorganism activity is influenced by the availability of $\mathrm{P}$ in the soil, so phosphate fertilizer for a source of nutrition for PSB activity needs to be given into the soil. However, phosphate fertilization should not excessively because it will suppess the activity and population of PSB.

Table 1. Population of Azotobacter, Azospirillum, and PSB in the rhizosphere of pakcoy plant at 4 WAP

\begin{tabular}{|cccc|}
\hline Treatments & $\begin{array}{c}\text { Azotobactersp. } \\
(\mathrm{cfu} / \mathrm{g})\end{array}$ & $\begin{array}{c}\text { Azospirillumsp. } \\
(\mathrm{cfu} / \mathrm{g})\end{array}$ & $\begin{array}{c}\text { PSB } \\
(\mathrm{cfu} / \mathrm{g})\end{array}$ \\
\hline K0N1 & $0,9 \times 10^{6} \mathrm{a}$ & $6,7 \times 10^{6} \mathrm{a}$ & $1,0 \times 10^{5} \mathrm{a}$ \\
K0N2 & $1,2 \times 10^{6} \mathrm{ab}$ & $8,6 \times 10^{6} \mathrm{bc}$ & $1,1 \times 10^{5} \mathrm{a}$ \\
K0N3 & $1,3 \times 10^{6} \mathrm{ab}$ & $7,2 \times 10^{6} \mathrm{~b}$ & $1,6 \times 10^{5} \mathrm{~b}$ \\
K1N1 & $2,6 \times 10^{6} \mathrm{c}$ & $11,6 \times 10^{6} \mathrm{c}$ & $2,1 \times 10^{5} \mathrm{c}$ \\
K1N2 & $1,6 \times 10^{6} \mathrm{~b}$ & $12,3 \times 10^{6} \mathrm{c}$ & $1,7 \times 10^{5} \mathrm{~b}$ \\
K1N3 & $1,7 \times 10^{6} \mathrm{~b}$ & $8,3 \times 10^{6} \mathrm{bc}$ & $1,2 \times 10^{5} \mathrm{ab}$ \\
\hline
\end{tabular}

Remarks: Means followed by the same letter on the line indicate no significant differences based on Duncan's Multiple Range Test at $\mathrm{p}<0.05$

EFB compost combined with inorganic fertilizers application increased the population of beneficial microbes such as Azotobacter, Azospirillum, and Phosphate Solubilizing Bacteria (PSB). Increasing the population of $\mathrm{N}$-fixing bacteria has the potential to reduce the requirement of synthetic $\mathrm{N}$ fertilizers, increase agricultural production and income with cheaper inputs (Setiawati et al., 2019). Suryatmana et al. (2020) stated that one of the efforts to increase microbial viability is by adding organic matter to the growing media. Organic materials can be used to maintain and increase cell viability and activity of Azospirillium sp.

\section{Pakcoy plant growth}


Pakcoy plant height at 4 WAP which was given EFB compost 10 t ha-1 with inorganic fertilizer $50 \%$ recommended dose showed higher growth than without EFB compost given inorganic fertilizer with the same dose. Meanwhile, the inorganic fertilizer dosage above 50\% with or without EFB compost showed no differently plant height. This indicates that the application of low doses of inorganic fertilizers needs to be accompanied by organic fertilizers in order to stimulate plant growth or increase plant height. Here, it can be seen that the function of organic fertilizers plays an important role in efficient absorption of plant nutrients, by giving applicating inorganic fertilizer 50\% was not showing different effect to the plant height compared with other treatments. Fertilization efficiency in vegetable crops can be done by adding organic matter, according to the opinion of Widowati (2009) that the application of organic fertilizers improve physical, chemical properties and increase fertilizer efficiency. The use of organic fertilizers can also reduce using of inorganic fertilizers, in accordance with the research application of $10 \mathrm{tha}-1$ of organic fertilizers with the use of a fertilizer dose of $50 \% \mathrm{~N}, 75 \%$ for P and K fertilizers increase fruit weight of tomato plants and increase fertilization efficiency (Subhan et al., 2005).

Pakcoy plant height growth took place in the vegetative growth phase. The vegetative growth phase of plants is associated with three important processes, namely cell division, cell

elongation, and the first stage of cell differentiation. These three processes require carbohydrates, because the carbohydrates combine with nitrogen compounds is important nutrient for to form building protoplasm during growing points which will affect to plant height increase. The availability of carbohydrates in plants is influenced by the availability of nutrients for these plants (Rosdiana, 2015).

\section{Table 2. Plant height and leaf number of pakcoy at 4 WAP}

\begin{tabular}{|ccc|}
\hline Treatments & $\begin{array}{c}\text { Plantheight } \\
(\mathrm{cm})\end{array}$ & $\begin{array}{c}\text { Numberofleaves } \\
\text { (strands) }\end{array}$ \\
\hline K0N1 & $24,20 \mathrm{a}$ & $15,00 \mathrm{a}$ \\
K0N2 & $25,25 \mathrm{ab}$ & $16,49 \mathrm{a}$ \\
K0N3 & $26,06 \mathrm{ab}$ & $15,91 \mathrm{a}$ \\
K1N1 & $27,00 \mathrm{~b}$ & $16,65 \mathrm{a}$ \\
K1N2 & $25,83 \mathrm{ab}$ & $17,33 \mathrm{a}$ \\
K1N3 & $25,79 \mathrm{ab}$ & $16,83 \mathrm{a}$ \\
\hline
\end{tabular}

Remarks: Means followed by the same letter on the line indicate no significant differences based on Duncan's Multiple Range Test at $\mathrm{p}<0.05$

The number of pakcoy leaves in all treatments did not show any difference. Pakcoy leaves for consumption do not include leaves damaged by pests and old yellow leaves (Figure 
1). Treatment of inorganic fertilizers without the addition of EFB compost resulted in a higher number of unfit for consumption leaves. This indicates that the application of EFB compost can reduce yield losses in pakcoy cultivation because organic fertilizers contain complete nutrition compared to only inorganic fertilizers. This phenomenon is supported by the opinion of Suriadikarta and Simanungkalit (2006) which states that the function of organic matter is to provide macro (N, P, K, Ca, Mg, and $\mathrm{S}$ ) and micro nutrients such as $\mathrm{Zn}, \mathrm{Cu}, \mathrm{Mo}, \mathrm{Co}, \mathrm{B}, \mathrm{Mn}$, and $\mathrm{Fe}$, although in relatively small amounts. The use of organic matter can prevent the deficiency of micro-elements in marginal soils or soils that have been cultivated intensively with unbalanced fertilization. The number of leaves is determined by the nutrients that are absorbed and converted into plant biomass. Gardner et al. (2008) stated that the increase in the number of plant leaves occurs due to cell division, an increase in the number of cells and an enlargement of cell size that requires energy in the form of ATP.

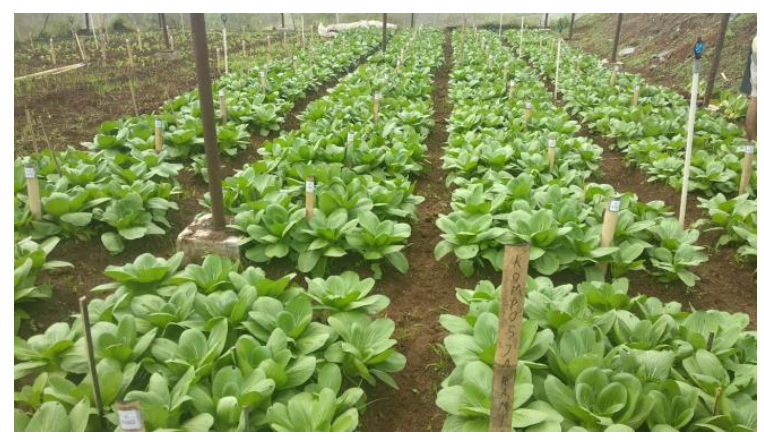

Pakcoy plants at 4 WAP

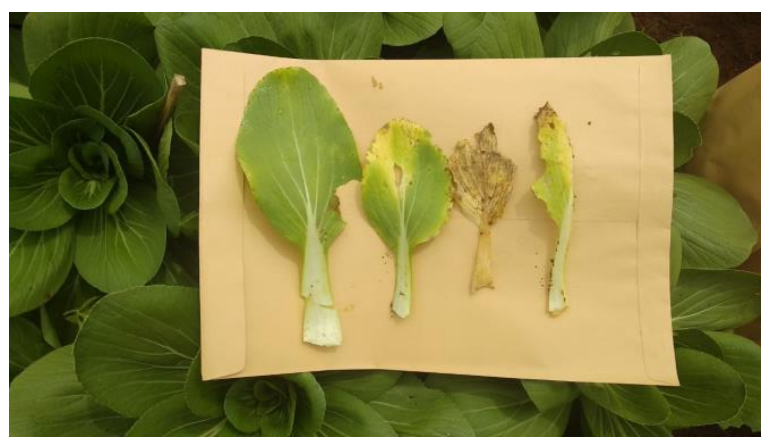

Damage by pests and diseases

A large number of leaves will produce more photosynthate because its have a greater the amount of chlorophyll on leaf. According to Patola (2008) leaves that have high chlorophyll content will be more efficient in capturing sunlight energy for photosynthesis and Hamin (2004) stated that wide leaves allow more photosynthesis to occur. So that the increase in photosynthesis will produce more photosynthatean which leading increase the dry weight of the top of the plant and produce energy for to form maintaining leaf quality.

Fresh weight of pakcoy plant

EFB compost combined with inorganic doses of 50\% and 75\% (K1N1, K1N2) application did not show differrent effect to the fresh weight of pakcoy plants compared with $100 \%$ inorganic fertilizer (K0N3) application. This means that application EFB compost can increase soil fertility. This impact showed in reducing inorganic fertilizer doses requirement. EFB compost enriched with PGPR microbes will have a dual function of providing a source of nutrition from organic matter and providing dissolved $\mathrm{N}$ and $\mathrm{P}$ for plants due to the activity of the PGPR bacteria. According to Hindersah et al., (2017) mixed inoculant biofertilizers reduce the level of inorganic fertilization.

Table 3. Yield of pakcoy at 4 WAP 


\begin{tabular}{|ccc|}
\hline Treatments & Freshweight per plant(g) & $\begin{array}{c}\text { Freshweightper plot } \\
(\mathrm{kg})\end{array}$ \\
\hline K0N1 & $197.58 \mathrm{a}$ & $4.109 \mathrm{a}$ \\
K0N2 & $197.04 \mathrm{a}$ & $4.082 \mathrm{a}$ \\
K0N3 & $196.85 \mathrm{ab}$ & $4.779 \mathrm{ab}$ \\
K1N1 & $219.67 \mathrm{ab}$ & $5.205 \mathrm{~b}$ \\
K1N2 & $287.77 \mathrm{~b}$ & $6.646 \mathrm{c}$ \\
K1N3 & $226.57 \mathrm{ab}$ & $5.095 \mathrm{~b}$ \\
\hline
\end{tabular}

Remarks: Means followed by the same letter on the line indicate no significant differences based on Duncan's Multiple Range Test at $\mathrm{p}<0.05$

The highest fresh weight of pakcoy per plot of $6.646 \mathrm{~kg}$ was shown on treatment of EFB 10 ton ha- 1 compost with a dose of inorganic fertilizer $75 \%$ of the recommended dose.

Application inorganic fertilizer dosage according to the recommended dosage (100\% inorganic) accompanied by EFB compost did not increase the yield of pakcoy plants. It is suspected that the addition of inorganic fertilizer dosage did not cause all inorganic fertilizers to be attach by EFB compost. Some of the inorganic fertilizers can be washed off during rain or volatilization. The provision of high doses of inorganic fertilizers presumably hampered the activity of PGPR bacteria in EMB compost in soil.

The results of this study illustrated that agricultural waste made from oil palm EFB has been proven potential to be used as organic fertilizer for pakcoy cultivation and can be combined with chemical fertilizers at low recomendation doses. This technology is suitable for agricultural practices that promote environmentally friendly. The effectivity of oil palm EFB organic fertilizer application will increase when combined with beneficial bacterial inoculants, which play a role in providing nutrients, especially $\mathrm{N}$. Nitrogen $(\mathrm{N})$ for improving the quality of leafy vegetable crops such as pakcoy. Wahyudin (2004) states that nutrients, especially nitrogen, play a very important role in plant vegetative growth. Nitrogen that absorbed by root with carbohydrate form proteins in leaves. The amount of nutrients absorbed by the roots will affect to the amount of nutrients adequacy, that will lead accelerate leaf growth, leaf formation, and increase the number of leaves and plant weight. Endang (2007) states that the rapid growth of the plants will increase the number of the leaves, so that the yeald of fresh weight of the plant will be higher. The improving formation of carbohydrates resulted from plant assimilation process will be increasing the plant fresh weight.

\section{CONCLUSION}


Oil palm empty bunches (EFB) compost enriched with PGPR bacteria can increase the population of beneficial bacteria in soil, growth, and yield of pakcoy. Application oil palm EFB compost 10 ton ha-1 with an inorganic fertilizer of $75 \%$ recommended dose resulted in high fresh weight pakcoy plants i.e $287.77 \mathrm{~g} /$ plant or $6.64 \mathrm{~kg} / \mathrm{plot}$.

\section{ACKNOWLEDGMENTS}

The author would like to thank Padjadjaran University for funding this research through the Unpad Lecturer Competency Research (RKDU) 2020 scheme. Thanks are also conveyed to our students Nizar Ulfah, Ibnu, Diyah, Camilla, Ahlan who helped this research.

\section{REFERENCES}

Abdulrahman D.K., Othman R., and Saud H.M. 2016. Effects of empty fruit bunch biochar and nitrogen-fixing bacteria on soil properties and growth of sweet corn. Malaysian Society of Soil Science . ISSN: 1394-7990 Malaysian Journal of Soil Science Vol. 20: 177-194 (2016)

Bot A. and Benites J. 2005. The importance of soil organic matter, key to drought resistant soil and sustained food production. Food and Agriculture Organization of the United Nations

Badan Pusat Statistika. 2018. Indonesia Oil Palm Statistics. Central Bureau of Statistics Indonesia

Elzebroek A.T.G and Wind K. 2008. Guide to Cultivated Plants. CAB International. London.

Endang. 2007. Effect of Doses of Organic Fertilizer and Nitrogen Fertilizer on Vegetative Growth of Cucumber (Cucumis sativus L.). Faculty of Agriculture. Bogor Agricultural Institute.

Gardner F.P., Pearce R.B., and Mitchel R.L. 2008. Cultivated Plant Physiology. Herawati Susilo translation. UI Press, Jakarta.

Hambali E., Mujdalipah S., Tambunan A.H., Pattiwiri A.W., dan Roy H. 2007. Bioenergy Technology. Agromedia Pustaka: Jakarta

Hamim. 2004. Underlaying Drought Stress Effect on Plant: Inhibition of Photosynthesis. Journal of Biosciences. 11(4):164169.

Hindersah R., Suryatmana P., Fitriatin BN, and Setiawati MR. 2017. Effect of Liquid Biofertilizer on Soil Nitrogen and Phosphorous and Yield of Choy Sum (Brassica rapa L.) Grown in Pot Culture. International Journal of Research in Engineering and Science. Vol 5 Issue 2: 2320-9364

Keeling A.A., Mullet J.A.J. and Paton I.K. 1994. Developments in the biology of compost processes. In: Rainbow, A.K.M (ed.). Why Recycle?. pp:1-5. Rotterdam, The Netherlands,

Kostov O., Rankov V., Atanacova G. and Lynch J.M. 1991. Decomposition of sawdust and bark treated with cellulose decomposing microorganisms. Biol. Fertil. Soils vol (11), no.2, pp. 105110 . 
Vol. 06, No. 01; 2021

ISSN: $2456-8643$

Kurniawan E., Murniati, and Armaini. 2016. The Effect of Formulations Compost Bunches Empty Oil Palm With Fertilizer NPK on The Growth and Production of Sweet Corn (Zea mays. L Var Saccarata Sturt). Jom Faperta Vol 3 No 1

Mujiyati dan Supriyadi. 2009. Pengaruh pupuk kandang dan ANORGANIK terhadap populasi bakteri Azotobacter dan Azospirillum dalam tanah pada budidaya cabai (Capsicum annum). Nusantara Bioscience 1: 59-64.

Patola E. 2008. Effect of urea dose and spacing of planting on the productivity of P-21 hybrid maize (Zea mays L). Journal of Agricultural innovation 7 (1): 51-65.

Pusat Penelitian Tanah dan Agroklimat (Center for Soil and Agro-climate Research). 2000. 2000. Indonesian Land Resources and Management. Bogor, Agricultural Research and Development Agency (BPPP).

Ramadhan C.I., Taryono, Wulandari R. 2014. Growth diversity and yield of five sugarcane clones (Saccharum officinarum L.) in Ultisol, Vertisol and Inceptisol soils. J. Vegetalika 3: 7787.

Rosdiana 2015. Pakcoy Plant Growth after Giving Rabbit Urine Fertilizer. Journal of Mathematics, Sience, and Technology, Volume 16, Number 1: 1-9. (Bahasa)

Sarapatka N. 2003. Phosphatase activities (ACP, ALP) in Agroecosystem Soils. Doctoral thesis. Swedish University of Agricultural Sciences. Uppsala.

Setiawati M.R., Aini H.F., Suryatmana P., and Hindersah R. 2019. Application of Inorganic Fertilizer and Bio-Fertilizer on Chlorophyll Content, $\mathrm{pH}$, and Leaves Number of Pak Choi (Brassica rapa L.) in Hydroponics. International Journal of Agriculture, Environment and Bioresearch Vol. 4, No. 04: 1-10.

Siddiquee S, Shafawati SN, Naher L. 2017. Effective composting of empty fruit bunches using potential Trichoderma strains. Biotechnol Reports. 13:1-7. doi: 10.1016/j.btre.2016.11.001.

Siddiqui Y, Meon S, Mohd RI, Rahmani M, Ali A. 2009. Efficient conversion of empty fruit bunch of oil palm into fertilizer enriched compost. Asian J Microbiol Biotechnol Environ Sci. 11(2):1-6.

Subhan N. Nurtika, dan W. Setiawati. 2005. Increasing Efficiency of Inorganic Fertilization by Utilizing Organic Ingredients on Tomato Yield. Journal of Horticulture 15 (2): 91-96.

Sudirja R., Sandrawati, A., Damayani, M., and Kamaluddin, N. N. (2019). Effect of Addition of Phosphate Fertilizer Doses on Growth and Yield of Corn (Zea mays L.) on Inceptisol from Jatinangor. Soilrens, 17 (1). (Bahasa)

Sugiyanta F. Rumawas M.A., Chozin W., Mugnisyah Q., and Ghulamahdi M. 2008. Study of N, $\mathrm{P}, \mathrm{K}$ nutrient uptake and yield potential of five lowland rice varieties (Oryza sativa L.) on inorganic and organic fertilizers. Bul. Agron. 36: 196-203. 
Vol. 06, No. 01; 2021

ISSN: $2456-8643$

Suriadikarta, D.A. and Simanungkalit R.D.M.. 2006. Organic fertilizers and biological fertilizers. J. Litbang Pertanian. 26: 1- 10.

Suryatmana P., Putri SR, Nadia Nuraniya Kamaluddin NN., dan Setiawati M.R. 2020. Potential of Organic Biostimulants Types in Increasing Population of Azospirillum sp, and Yield Soybean (Glycine max. L.) in Inceptisol Jatinangor. Soilrens, Volume 18 No. 1.

Syafwina Y. Honda, T. Watanabe and M. Kuwahara. Pretreatment of palm oil empty fruit bunch by white-rot fungi for enzymatic saccharification. Wood Research. 2002; 89:19-20

Wahyudiin. 2004. The effect of urea dosage and multitonic foliar fertilizer on the growth and yield of green pakcoy cultivar caisin. Department of Agricultural Cultivation, Faculty of Agriculture, Siliwangi University. Tasikmalaya

Widowati, L.R. 2009. The role of organic fertilizers on fertilization efficiency and the level of need for vegetable crops in Ciherang Inseptisols. J. Tropical Soil. 14: 221-228. 